Article

\title{
Application of Digital Techniques in Industrial Heritage Areas and Building Efficient Management Models: Some Case Studies in Spain
}

\author{
Carlos J. Pardo Abad ${ }^{\dagger}$ \\ Department of Geography, Universidad Nacional de Educación a Distancia, 28040 Madrid, Spain; \\ cjpardo@geo.uned.es \\ + Co-director of the "Geography, Landscape and Information Technology" research group.
}

Received: 19 September 2019; Accepted: 15 October 2019; Published: 18 October 2019

\begin{abstract}
This research represents a novel contribution regarding the application of digital technology to the management and cultural promotion of industrial heritage. The study answers questions about the level of digital transformation of certain preselected buildings and areas of great historical and technical interest. It includes an extensive bibliographic review and analyzes different variables linked to webpages, which are the main source of information for visitors, and studies the level of digitization using a survey of the technical managers. The results are valuable because they offer an original profile of selected industrial heritage sites, characterized by an important connection between visitors, visited spaces, and available resources; the interaction of these three elements with the surrounding territory, fostering a new competitive capacity; the projection of each place in a modern and attractive way; and the commitment to an efficient and sustainable local management model. The results provide a fresh look at the technological changes embodied by new uses in old industrialization sites. In addition, the performed analysis could easily be applied and operationally compared in other different heritage environments.
\end{abstract}

Keywords: digital transformation; industrial heritage; efficient management; ICTs

\section{Introduction}

The information and knowledge society, internet, e-commerce, connectivity breakthroughs or the generalization of mobile devices and applications have prompted a new technological framework that has greatly impacted all social, economic, and cultural activities. One of the sectors affected most heavily has been tourism, as it aims to adapt to generalized hyperconnectivity and highly interactive tourists.

Visits to former industrial sites are increasingly linked to the expansion of communication channels and the generalization of increasingly sustainable and effective management models. The digital transformation of industrial heritage sites boosts the influx of tourists and their degree of satisfaction which, in turn, encourages the conservation of other historical industrialization sites. This reinforces the role of industrial heritage as an emerging cultural resource of great potential for tourism.

The legacy of industrialization must now be re-read from an integrated, scientific, and innovative perspective: (i) Integrated, because you cannot interpret isolated objects from each other or outside the environment in which they are located, and this implies a territoriality of unquestionable geographical value; (ii) Scientific, because there can be no more purely descriptive approaches to heritage resources, as occurs in a first phase of discovering and cataloguing the industrial heritage, without explanatory causal references; and (iii) Innovative, because a new information and communication technologies-based framework must be built around industrial heritage as a vehicle for the promotion 
of the destinations, dissemination of associated values, and active interpretation of exhibition contents. At the same time, this threefold aspect serves to ensure resources are managed better.

Through the advanced application of digital techniques, a traditional destination can be turned into a smart destination [1-4]. All these authors consider that these spaces are always linked to technological competitiveness and to improving tourists' experience. Innovative places supported by cutting-edge technological structures that allow for the sustainable development of resources and the integration of visitors with the architectural, environmental, and socioeconomic environment [5].

The application of new technologies in the management of industrial heritage areas and buildings differs from one case to another, but progress, in general, has been positive. New applications and platforms have created great opportunities to bring the legacy of industrialization to the attention of the general public by letting them interact easily and permanently with the resources offered. In this respect, instead of only considering a few issues, like energy efficiency, the sustainability of the retrieved mining and industrial landscapes, the environmental regeneration of the sites, new local employment opportunities, and now, other, more technological aspects linked to information and communication are also taken into account. The spotlight has switched from the place to the visitor, through a multiple sequence of intelligent interpretation of resources.

By creating a complete and effective information system, all involved players can be better coordinated, and goals can be defined more soundly, fostering broader collaboration networks $[3,6]$.

The implications of using ICTs (information and communication technologies) to manage destinations and the strategic, technological, and innovation-oriented vision that presides over new tourism are at the heart of some of the research carried out so far [7-9]. Innovation has been always very significant in relation to competitiveness. It entails processes that affect all players in different contexts and must rely on the development of ICTs to maintain an active interdependence between people and technology. This creates an ecosystem in which multiple human, technical, and economic resources are combined in the form of essential components of tourism intelligence [10].

Cultural tourism could stand to benefit the most from technological advances and the proliferation of new communication tools. Cultural resources are basic for heritage destinations or even complementary for other destinations and, in some cases, heritage preservation is a fundamental precondition for developing the tourist function of the territory and conceptualizing the so-called "territorial heritage system" [11]. Their online promotion and dissemination is an extraordinary opportunity to boost their appeal [12].

Some authors suggest that despite the advantages that ICTs bring by connecting tourists and resources, cultural tourists like to contemplate the original version of the material or intangible item and experience it first-hand. In this regard, new information and communication technologies are not really interpreted as a substitute but, rather, as a complement to the personal experiences recorded during the trip and an instrument to better understand the contents [13,14].

The connection through digital dialogue between institutions, visitors, and objects implies a collaborative approach that increases the opportunities for personal interpretation of resources. This is what underlies a new concept, namely, smart cultural heritage spaces $[15,16]$. These authors reckon that these spaces can shorten the distance between cultural heritage and visitors and, to a certain extent, overcome the remaining idea that cultural objects are to be enjoyed in a purely aesthetic and essentially passive way.

For all these reasons, new ICTs have unquestionably taken center stage in many of the most recent projects which base their interventions on offering more information, more efficient management, more active visitor participation, and generally reshaping their strategies. It is not simply a matter of replacing heritage resources with digital tools, but of offering more data and participatory services online [17].

Industrial heritage is an emerging cultural resource, although it is still not appreciated enough. The enhancement of its different components has prompted an extensive process of opening up of museums, interpretation centers, cultural parks, ecomuseums, and museum territories [18]. It is 
essential that all these proposals regarding the exhibition, visualization, and interpretation of industrial heritage be adapted to the powerful existing technological framework. Technological development has created a new cultural reality in industrial heritage. It is a reality defined by ICTs. Digital tools make industrial heritage an intelligent heritage. The most important ones are the following: websites; 3D models; geolocation systems; generation and management of digital representations of physical and functional characteristics of buildings and areas (BIM models); social networks; podcasting; mobile phone apps; QR codes; augmented reality; and multimedia guides.

To date, there has yet to be an in-depth study of the opportunities that new technologies can afford in the industrial heritage field. There are practically no references in this regard, and those that do exist are not very precise and limited to the use of a few general concepts and management models. In some cases, they spotlight industrialization's legacy in the so-called smart territories and the possible advantages of applying innovative techniques [19].

In the field of geography, there are very few investigations related to the new technologies applied to industrial heritage. The studies have basically focused on the analysis of post-industrial landscapes and the transformations experienced from an aesthetic and functional point of view, as well as on the territorial representation of the built elements inherited from industrialization.

As already mentioned, there is some concrete reference to the advantages that the application of technological innovation could have in the management of industrial heritage, all within the framework of the so-called smart territories. It is a geographical vision of undoubted interest that only represents a small approximation to the subject in question.

More specifically, the application of new technologies in the field of heritage education has been addressed, with specific references to industrial heritage [20]. These authors focus on the interpretation of cultural itineraries of industrial heritage, with several case studies in the city of Madrid. The design of a mobile app and its valuation by users becomes the main objective of the research, with an obvious geographical meaning and promotion of the values associated with industrial heritage.

The challenges posed to tourism by the new trends in demand and consumption are based, above all, on the use of new technologies at the service of the best tourist lending. In recent times, the so-called smart destinations have been configured, a new tourism paradigm of deep geographical connotations due to their characteristics of innovative spaces supported by a cutting-edge technological structure, which guarantees the sustainable development of the tourist territory [5].

The particularities of each tourist territory require the implementation of the most appropriate digital solutions [3]. In some cases, the complicated relationships that exist around the large number of local agents involved in tourist destinations (including industrial heritage) are discussed, which makes it difficult to apply digital tools for configuration as smart destinations [21,22]. In any case, the territorial scale of the local type is the most appropriate to promote the digital challenge and overcome the limitations of tourist sites [23]".

Other times, industrial heritage is regarded as a very specific legacy with a great capacity for coordinating territories and resources. The main goal of some authors is to try to define a conceptual model of smart or technological industrial heritage tourism [24]. That task involves developing far more complex forms of management that can be adapted to digital techniques.

These authors define what they call the smart industrial tourism business ecosystem (SITBE) model. It is based on the premise that industrial heritage, considered as a cultural resource, not only calls for investments in the physical recovery of the elements, but also in a range of actions designed to create collaborative organizational structures; involving the local business fabric; boosting technological competitiveness; interacting with the local community; and building a technological model based on intelligent information and communication.

This study mainly aims to ascertain the level of technological innovation at certain industrial heritage sites, chosen on account of their special significance as cultural and tourist resources, and to determine the extent to which digitization enhances efficient management. Another albeit secondary 
objective is to identify the problems and opportunities found when configuring technically smart industrial heritage destinations.

The lack of specific studies in this field makes it essential to conceptualize what one could refer to as smart industrial heritage spaces; innovative places equipped with technological infrastructure that facilitates permanent access to information, visitor interaction, and sustainable management. Applying digital techniques and platforms in the industrial heritage environment increases the quality of destinations, improves and promotes visitors' active and shared tourist experience, and drives the environment's cultural, environmental and socioeconomic factors as economic development drivers.

\section{Method}

In this study, we selected eleven different industrial heritage sites, including both isolated constructions and large building complexes, located in the autonomous regions of Andalusia, Castile-La Mancha, Murcia Region, Basque Country, Castile-León, Catalonia, and Asturias. They represent some of the most heavily industrialized sites in Spain's history, which is why it matters so much to ascertain the current level of digital transformation of their management and promotion. In some cases, they are areas with a long-standing mining tradition and a strong initial environmental impact, with interesting constructions and tools of different types [25]. Spectacular landscapes that still bear the deep traces of an activity that lasted a very long time and has resulted in intensive regeneration [26]: Riotinto (Huelva), Almadén (Ciudad Real), La Unión (Murcia), and Samuño (Asturias). The Añana Salt Mines (Alava) are the last example of mining sites selected in the research project.

All other cases involve specific buildings and constructions from different productive sectors adapted to manufacturing techniques. Some date back to the pre-industrial era, like the San Blas Ironworks (León), the Royal Glass Factory in La Granja de San Ildefonso (Segovia), and the Royal Spanish Mint in the city of Segovia [27,28]. Others date back to the industrial era per se, such as the La Encartada Beret Factory in Balmaseda (Vizcaya), the water lift in Cornellà del Llobregat (Barcelona), and the Vapor Aymerich, Amat y Jover textile factory in Tarrasa (Barcelona) (Figure 1).

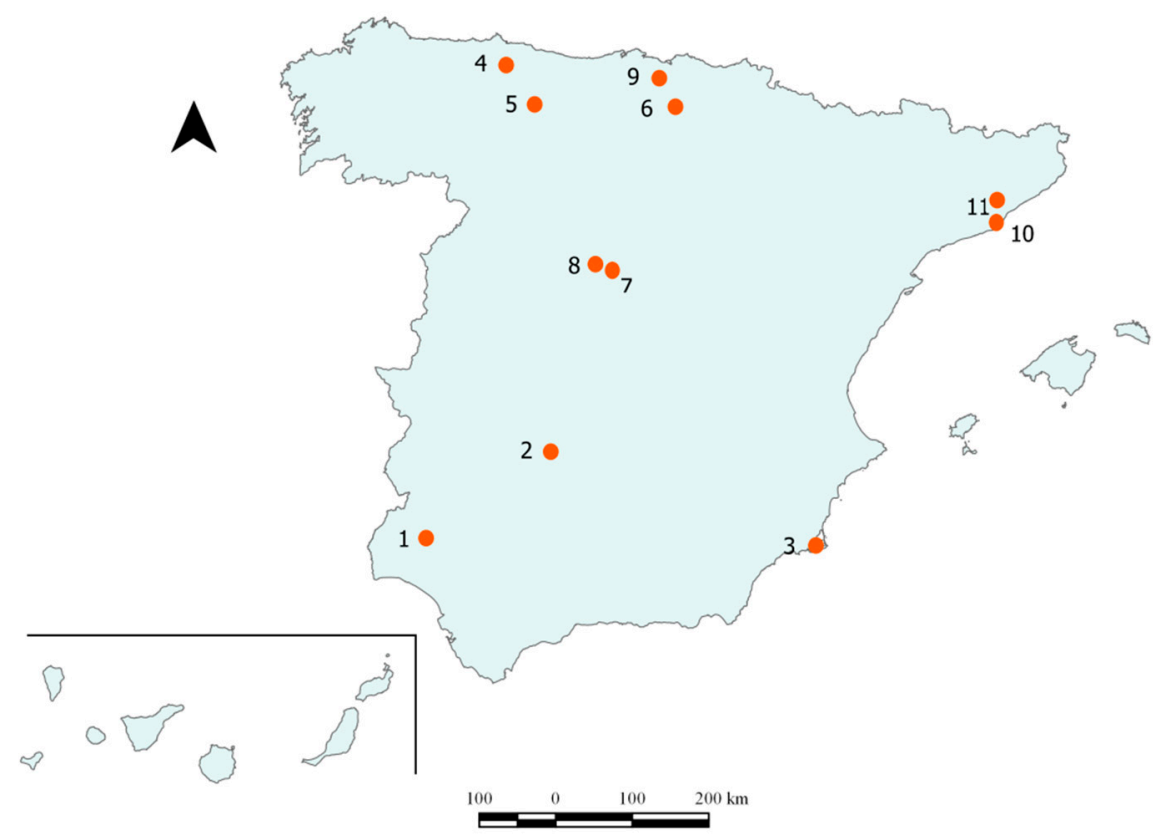

Figure 1. Location of buildings and areas analyzed: 1. Riotinto mining area; 2.Almadén mining area; 3. La Unión mining area; 4. Samuño mining area; 5. San Blas Ironworks; 6. Añana Salt Mines; 7. Royal Glass Factory; 8. Royal Spanish Mint; 9. La Encartada Beret Factory; 10. Water lift; 11. Vapor Aymerich, Amat y Jover textile factory. Source: José Fernández Álvarez (UNED SIG Laboratory). 
From a methodological viewpoint, an extensive review of the scientific literature has been conducted to verify the different theoretical approaches present in the smart tourism field, the application of new digital technologies, and the proposed innovative resource management models. Also with regard to the method, one proposal put forward is to analyze them by using different variables present on their webpages, creating an index and conducting a survey.

Use of the web popularity index (WPI) is proposed to check and measure the variables regarding the content and information available on the webpages. The WPI, which ranges from 0 to 1 , measures the percentage compliance of a broad range of selected variables that each industrial heritage site had in February 2019. The results are analyzed both in terms of constructions and sites and of variables; in other words, identifying the mean value obtained in each building and site for all variables and of each variable for all case studies.

The WPI is a very interesting tool in this investigation. It is considered a fundamental part of the study not previously used by other researchers. Obtaining the indicator is quick and simple, and the results are very direct and understandable from the point of view of the technological reality used in the case studies. The WPI quantifies different and highly significant qualitative aspects and is very useful in two ways: first of all, it is an efficient, straightforward, and simple way of approximating the information facilitated to visitors; and, secondly, it can be used to categorize the sites and buildings selected in terms of their level of application and display in digital environments.

A key part of the method has been the survey, carried out between the months of March and April 2019, among the technical managers and directors of the selected industrial heritage sites. The blocks and questions are listed in Table 1 below, and the levels of response were limited to three categories: agree, disagree, and no opinion. The survey, divided into five blocks and thirty different questions with one final open-ended question, has provided digital reality information about the management, sustainability, accessibility, connectivity, innovation, and use of ICTs.

Table 1. Blocks and questions in the model survey conducted.

\begin{tabular}{|c|c|}
\hline Block & Question \\
\hline $\begin{array}{l}\text { (A) General solutions and trends for creating a } \\
\text { smart building or site }\end{array}$ & $\begin{array}{l}\text { 1. The current technological scenario offers interesting opportunities in } \\
\text { this respect } \\
\text { 2. Implementing technology is regarded as a renewal and revaluation } \\
\text { measure in any case } \\
\text { 3. New technologies favor greater interaction between visitors, } \\
\text { buildings, or sites } \\
\text { 4. Applying technology is perceived as a good management move } \\
\text { 5. Applying new technologies is complex and sometimes problematic } \\
\text { 6. When applying technologies, the economic cost is considered a } \\
\text { decisive factor }\end{array}$ \\
\hline $\begin{array}{c}\text { (B) Specific solutions and trends for the } \\
\text { industrial heritage building or site } \\
\text { management }\end{array}$ & $\begin{array}{l}\text { 7. Technology is already playing a key role in the management and } \\
\text { promotion of your industrial heritage building or site } \\
8 \text {. Using new technologies is considered to provide greater efficiency } \\
\text { and reduces costs to a great extent } \\
9 \text {. The members and workers of the industrial heritage building or site } \\
\text { are aware of and properly trained in new digital technologies } \\
\text { 10. There is a suitable level of collaboration between different (public } \\
\text { and private) local and regional entities for implementing technology in } \\
\text { the industrial heritage building or site } \\
\text { 11. The municipal authorities help to promote the site or building as a } \\
\text { smart space } \\
\text { 12. The industrial heritage building or site has a specific strategy for } \\
\text { becoming a smart space } \\
\text { 13. The industrial heritage building or site is evolving favorably towards } \\
\text { being considered a smart space }\end{array}$ \\
\hline
\end{tabular}


Table 1. Cont.

\begin{tabular}{|c|c|}
\hline Block & Question \\
\hline $\begin{array}{l}\text { (C) Specific solutions and trends for the } \\
\text { industrial heritage building or site: } \\
\text { sustainability and accessibility }\end{array}$ & $\begin{array}{l}\text { 14. The industrial heritage building or site is sustainable in relation to } \\
\text { the conservation of the surrounding landscape and the available } \\
\text { resources } \\
\text { 15. The industrial heritage building or site applies light energy saving } \\
\text { by using led technology } \\
\text { 16. The industrial heritage building or site has lighting control sensors } \\
\text { based on luminosity conditions } \\
\text { 17. The industrial heritage building or site applies water saving } \\
\text { measures } \\
\text { 18. The zone is accessible for disabled people } \\
\text { 19. The industrial heritage building or site has tactile models that can be } \\
\text { interpreted by the visually impaired } \\
\text { 20. Digital access to all the information about the industrial heritage } \\
\text { building or site is promoted }\end{array}$ \\
\hline $\begin{array}{l}\text { (D) Specific solutions and trends for the } \\
\text { industrial heritage building or site: } \\
\text { connectivity and innovation }\end{array}$ & $\begin{array}{l}\text { 21. Internet connectivity is adequate } \\
\text { 22. You can log onto free Wi-Fi networks } \\
\text { 23. The industrial heritage building or site is innovative regarding the } \\
\text { inclusion of new technologies } \\
\text { 24. The industrial heritage building or site has a tourist application for } \\
\text { smartphones } \\
\text { 25. The industrial heritage building or site has interpretive panels with } \\
\text { QR codes } \\
\text { 26. The QR codes are included in the printed promotional material }\end{array}$ \\
\hline $\begin{array}{l}\text { (E) Specific solutions and trends for the } \\
\text { industrial heritage building or site: } \\
\text { application of information and } \\
\text { communication technologies (ICTs) }\end{array}$ & $\begin{array}{l}\text { 27. These technologies are used to know more about registered visits } \\
\text { 28. ICTs are used to ensure better management of the resources of the } \\
\text { industrial heritage building or site } \\
\text { 29. ICTs are used in the promotion of the industrial heritage building or } \\
\text { site } \\
\text { 30. ICTs are used to improve visitors' experience in the industrial } \\
\text { heritage building or site }\end{array}$ \\
\hline
\end{tabular}

Source: own elaboration.

\section{Results}

The internet is one of the biggest information access windows, and instantly provides knowledge to a large part of the world's population. This technology is essential for making industrial heritage more accessible and making the historic heritage of industrialization more visible.

Tourists have become more and more interested in ICTs over the latest decades and it is calculated that right now, around $45 \%$ of internet searches about tourism in Spain, similarly to all other developed countries, are related to cultural aspects.

Webpages are the main source of information that people look at when planning a trip, so a building or place stands to gain a lot in information and value terms if it has an attractive, well-designed website. The fact that industrial heritage appeals to a selective, minority kind of tourism reinforces the idea that it is essential to have a technological scenario appropriate to the digital tourist's needs and to "democratize" online knowledge of industrialization's heritage and the final success of new-use projects.

\subsection{Webpages and Digital Display of Content}

In order to analyze the webpages of the cases selected for the study, first, a total of 14 different variables regarding the digital information available to tourist were established. Those variables are (i) attractive design and well-structured content; (ii) presentation of interesting content; (iii) smart event calendar log; (iv) availability of weather information; (v) access to multilingual information; (vi) possibility of booking tickets online; (vii) online promotion of other representative tourist attractions; (viii) destination displayed with Google Maps ${ }^{\mathrm{TM}}$ and/or Street View; (ix) possibility of using mobile device applications; $(x)$ integrated presence in social media (Facebook, Twitter, YouTube, etc.); (xi) possibility of giving opinions and ratings; (xii) availability of a virtual tour; (xiii) access to PDF 
digital leaflets in or 3D models from photographs; and (xiv) access to multimedia tools (videos, audios, augmented reality, etc.).

The heritage site with the highest web popularity index (WPI) is the Almadén mining area (now the Almadén Mining Park) (Figure 2). The next buildings or areas, with a slightly lower WPI, are as follows: Vapor Aymerich, Amat y Jover textile factory (now the Catalonia National Museum of Science and Technology, MNACTEC), water lift (now the AGBAR Water Museum), Royal Glass Factory (now the Glass Technology Museum), Real Casa de la Moneta, Añana Salt Mines and San Blas Ironworks (now the Castile-León Iron \& Steel and Mining Museum). Almost all the specified variables are present in this first level of selected buildings and areas, which can be regarded as spaces with a highly technological web presence. Their webpages offer a varied range of information and digital resources of different kinds, in line with the expectations generated as sites that are highly symbolic as far as industrial heritage is concerned. In all these cases, the web popularity index is equal to or higher than 0.78 .

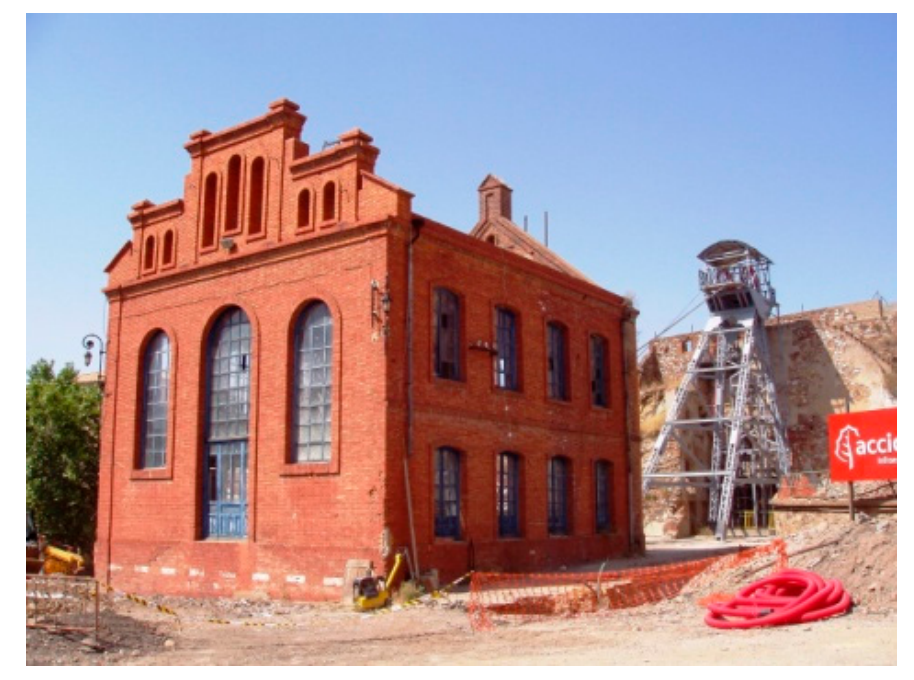

Figure 2. Almadén mining area. Author: Carlos J. Pardo Abad.

On a second level are all the other analyzed cases with lower scores than the first group, between 0.78 and 0.43 , namely, the Riotinto, La Unión, and Samuño mining areas (all three of which have been turned into mining parks and receive a large number of visitors every year). The La Encartada Beret Factory ranks last among all the cases studied with a WPI of 0.43 . According to these figures, each selected building and site ranks in different positions, depending on the level of technology applied on their webpages (Figure 3).

The general average of the complied variables is $70 \%$, which represents a good level as a whole, but could be improved in certain aspects. The variable with the highest level of compliance refers to the presentation of interesting content $(100 \%)$, followed by the attractive design and well-structured content (91\%), smart event calendar log $(91 \%)$, online promotion of other representative tourist attractions (91\%), and integrated presence in social media (91\%). The access to multilingual information, destination displayed with Google Maps ${ }^{\mathrm{TM}}$ and/or Street View, and access to PDF digital leaflets or photograph-based 3D model variables were complied with in $82 \%$ of cases.

In the other variables, the compliance percentages ranged from $73 \%$ to $1 \%$. Weather information was only available in one of the selected cases, which is quite surprising as weather conditions affect the number of people visiting industrial heritage buildings and sites. Levels of presence are also low in the variables regarding the possibility of using mobile device apps $(18 \%)$ and the availability of a virtual tour (36\%). The possibility of expressing opinions and giving scores online is clearly above average $(64 \%)$, while compliance with the other variables is around $70 \%$ (Table 2). 


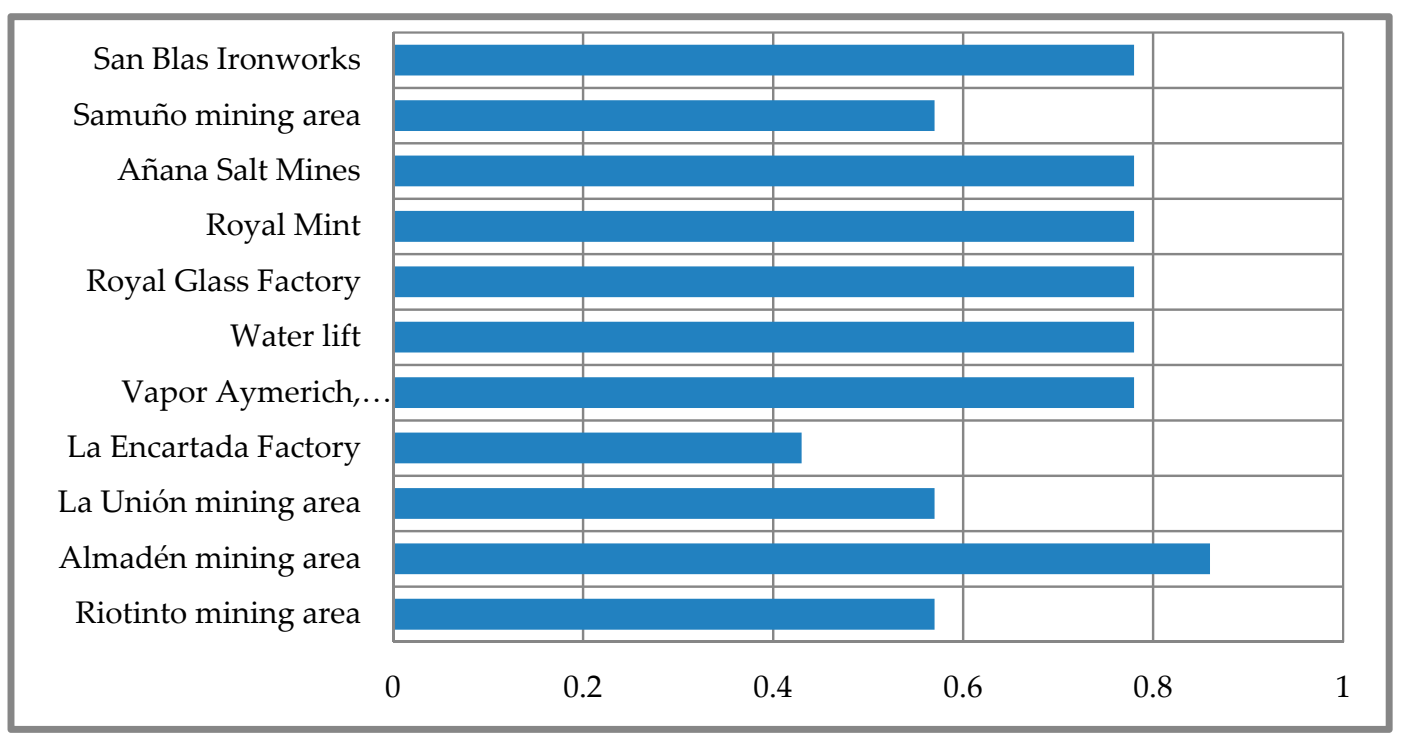

Figure 3. Web popularity index (WPI) of industrial heritage buildings or areas. Source: own elaboration.

Table 2. Overall level of compliance of the selected variables.

\begin{tabular}{lc}
\hline \multicolumn{1}{c}{ Variable } & Percentage \\
\hline 1. Attractive design and well-structured content & 91 \\
2. Presentation of interesting content & 100 \\
3. Smart event calendar log & 91 \\
4. Availability of weather information & 1 \\
5. Access to multilingual information & 82 \\
6. Possibility of booking tickets online & 73 \\
7. Online promotion of other representative tourist attractions & 91 \\
8. Destination displayed with Google Maps ${ }^{\mathrm{TM}}$ and/or Street View & 82 \\
9. Possibility of using mobile device applications & 18 \\
10. Integrated presence in social media (Facebook, Twitter, YouTube, etc.) & 91 \\
11. Possibility of giving opinions and ratings & 64 \\
12. Availability of a virtual tour & 36 \\
13. Access to PDF digital leaflets in or 3D models from photographs & 82 \\
14. Access to multimedia tools (videos, audios, augmented reality, 360 & \\
panoramas, etc.) & 73 \\
Mean value $(\overline{\mathbf{X}})$ & 70 \\
\hline
\end{tabular}

Source: own elaboration.

Multilingual information can be found at all the selected sites, except in the La Unión and Samuño mining areas. In the other case studies, information is always offered in Spanish and English and, more specifically and occasionally, in other languages. On the issue of this variable, it is striking that on the Riotinto area website (Figures 4-6)_corresponding to an area in the province of Huelva close to the Portuguese border and which attracts numerous visitors from the neighboring country-the information is not available in Portuguese. 


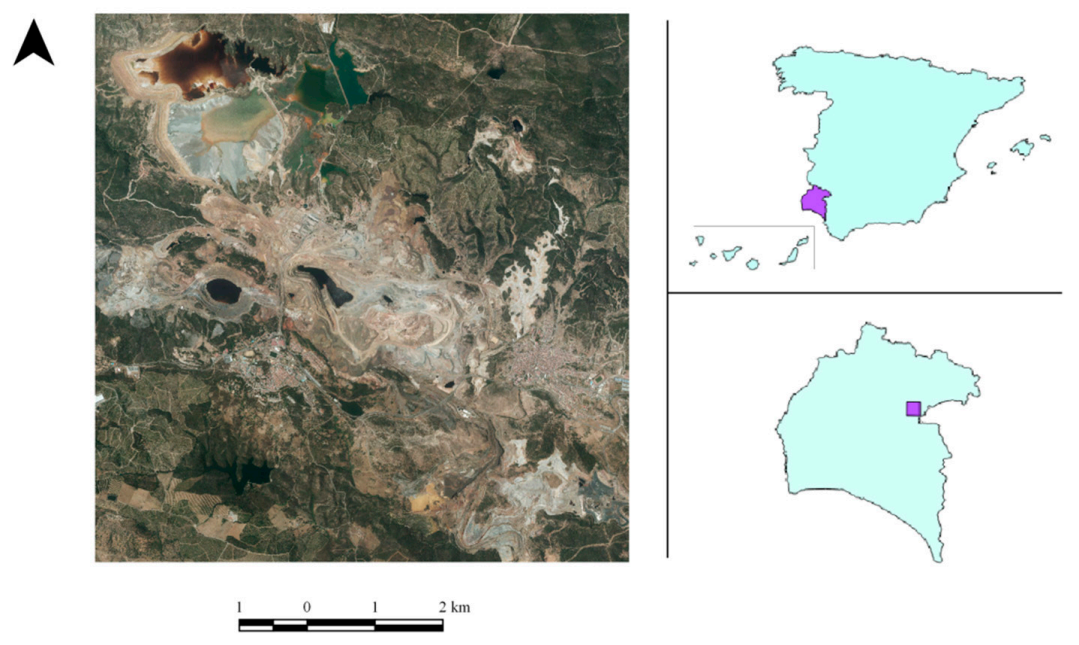

Figure 4. Orthophoto and location of the Riotinto mining area. Source: José Fernández Álvarez (UNED SIG Laboratory).

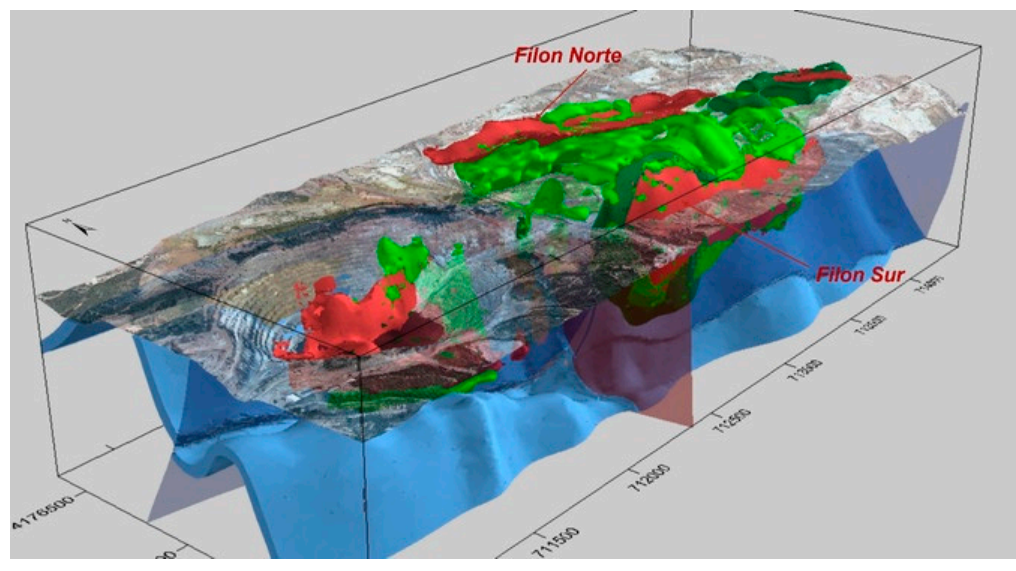

Figure 5. 3D model of the Riotinto mining area [29]. This figure shows an axonometry, from the SE, of the open pit mines of Cerro Colorado and Corta Atalaya. In blue, the anticline bounded by the northern and southern faults. The zones of copper mineralization appear in green and the pyritic stockwork appear in red.

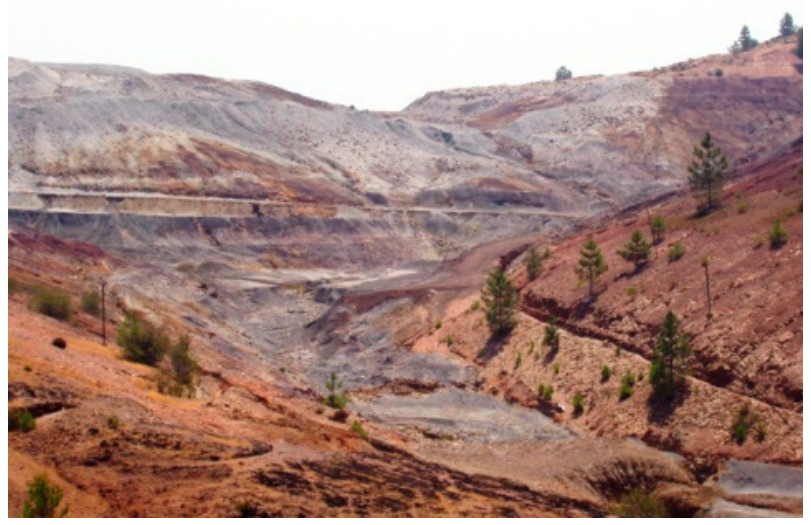

Figure 6. Riotinto mining area. Author: Carlos J. Pardo Abad. 


\subsection{Survey and Inference of the Level of Technological Management}

The survey used was sent to the technical managers of the selected heritage sites and constructions, with several sets of questions on management, sustainability, accessibility, connectivity, innovation, and ICT usage. The level of response was $64 \%$, meaning that the results are reliable. The survey was divided into five blocks, to which a final open-ended question was added. The first block (Block A) was of a general nature, and was entitled "General solutions and trends for creating a smart building or place". The next ones refer exclusively to the level of technological intelligence applied to each selected industrial heritage site: the second block (Block B) is on "management", the third (Block C) on "sustainability and accessibility", the fourth (Block D) on "connectivity and innovation", and the fifth (Block E) on "application of information and communication technologies". These blocks can be seen in Table 3.

Table 3. Summary of the levels of response by survey blocks.

\begin{tabular}{ccccc}
\hline Blocks & Thematic Area & Agree (\%) & Disagree (\%) & No opinion (\%) \\
\hline Block A & General & 83 & 14 & 3 \\
Block B & Management & 50 & 40 & 10 \\
Block C & Sustainability and accessibility & 73 & 22 & 5 \\
Block D & Connectivity and innovation & 50 & 48 & 2 \\
Block E & ICT & 61 & 21 & 18 \\
Total & & 63 & 29 & 8 \\
\hline
\end{tabular}

Source: own elaboration. Note: highlighted fields have the highest response percentages.

Table 3 shows a general summary of the survey answers, with average percentages for all the questions contained in each block. There is a majority of "Agree" answers in all cases, especially Block A, with $83 \%$ as the highest score, and Blocks B and D, with $50 \%$ as the lowest scores. Therefore, it is these last two blocks that have the highest percentages of "Disagree" answers, with $40 \%$ and $48 \%$, respectively.

Worth highlighting about the results of the first block of the survey (Block A) is that all the site managers agreed that the current technological scenario offers interesting opportunities for building a smart space. They also appreciate that technologies foster greater interaction with visitors.

There were bigger differences in the other questions of this block because $83 \%$ agreed that implementing technology is a means of renewing and reasserting the value of the site, as well as improving their management, while the remaining $17 \%$ disagreed. The same response percentages were obtained in the question as to whether economic cost is considered a decisive factor when applying technologies. In the last question of this first block, $50 \%$ of the respondents agreed with the idea that applying new technologies is complicated.

As explained earlier, the following four blocks of questions refer to the specific heritage building or area. On the management issue (Block B), 50\% of respondents saw technological solutions and trends as a good option for managing industrial heritage, although a not too insignificant percentage, $40 \%$, disagreed. The remaining $10 \%$ had no opinion.

Asked about whether technology already plays a fundamental role in management and promotion, $50 \%$ of the sample agreed and the other $50 \%$ disagreed. There were greater imbalances in the answers to the other questions. Around $83 \%$ agreed with the fact that using the new technologies affords greater efficiency and cuts costs. Around $66 \%$ considered that the industrial heritage building or area's members and workers are sensitized to and properly trained in new digital technologies, and $83 \%$ of respondents believed that local and regional entities do not cooperate enough in implementing technology, but did acknowledge the role played exclusively by municipal authorities.

The surveys show that $50 \%$ of the museums open in the industrial heritage building or sites already have a specific strategy for becoming a smart tourist destination. This positive situation is linked directly to the idea that the building or place is evolving favorably towards being considered a 
smart space in $66 \%$ of cases. In any case, it seems that all the measures devised to further promote these strategies in the short and medium term need to be increased.

The next block of the survey (Block C) has to do with two basic issues of great importance for the promotion of the preserved assets: sustainability and accessibility. It was found that $73 \%$ of the surveyed places already apply sustainable measures, such as energy and water saving, aesthetic conservation of the landscape, and maintenance of available heritage resources. Also worth noting are the site accessibility-related measures. Only $22 \%$ disagreed and the remaining $5 \%$ had no opinion.

In all cases, respondents considered that the industrial heritage building or site is already sustainable in relation to the landscape and available resources. This level of response represents full awareness regarding the aesthetic value of the environment in this type of heritage (especially notable in mining areas). The landscape and architectural or technical resources are always stimulating factors in the cultural promotion of the places and as spaces that are locallybased identity reference points.

The levels of responses about energy or water saving measures differed more. In most cases, they are already applied in lighting (86\%) with the use of LED technology, and in $14 \%$ of cases, there are sensors for regulating lighting in terms of light conditions. Water saving measures are in place in $72 \%$ of cases.

Physical and digital accessibility is another important aspect in this block. According to $86 \%$ of respondents, the industrial heritage building or area is accessible to people with physical disabilities. As regards visual disability, only $57 \%$ of the sites have tactile models that can be interpreted by the blind or visually impaired; and when asked about digital accessibility, all the selected places said that they promote web access to all their information.

The next block of questions (Block D), penultimate of the whole survey, refers to connectivity and innovation. Broadly speaking, $50 \%$ of respondents considered that the level of application is not yet high enough, while $48 \%$ agreed and the remaining $2 \%$ had no opinion.

Internet connectivity is adequate at the destination in $86 \%$ of cases, but free Wi-Fi networks are only available at $28 \%$ of the sites. This result is especially striking because it is one of the technological measures that is easiest to apply. Similar figures ( $28 \%$ agree) were obtained when asked about the availability of a tourist app for smartphones (Figures 7 and 8 ).

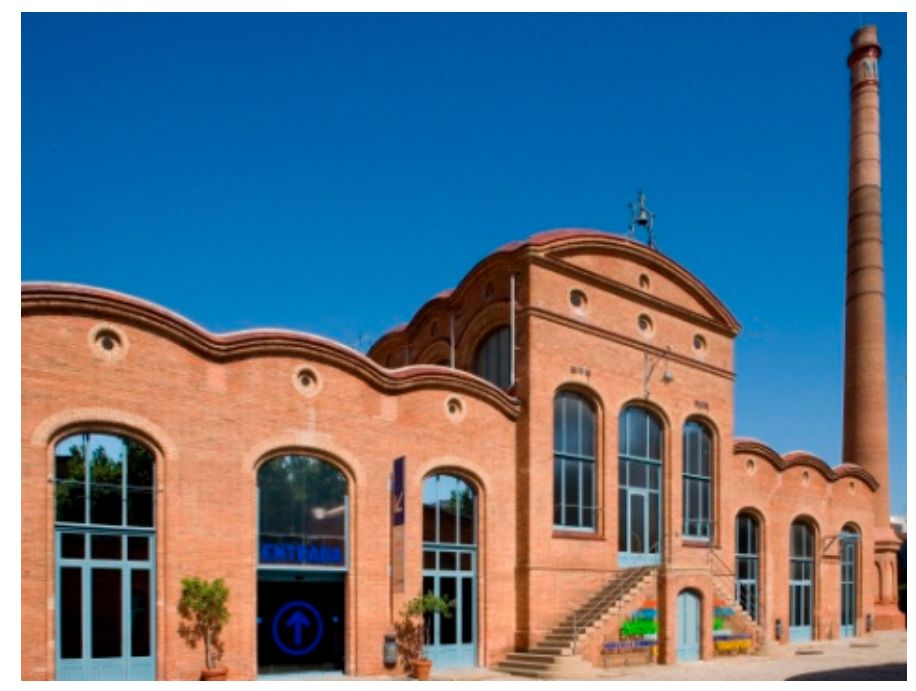

Figure 7. Vapor Aymerich, Amat y Jover (MNACTEC). Author: Carlos J. Pardo Abad. 

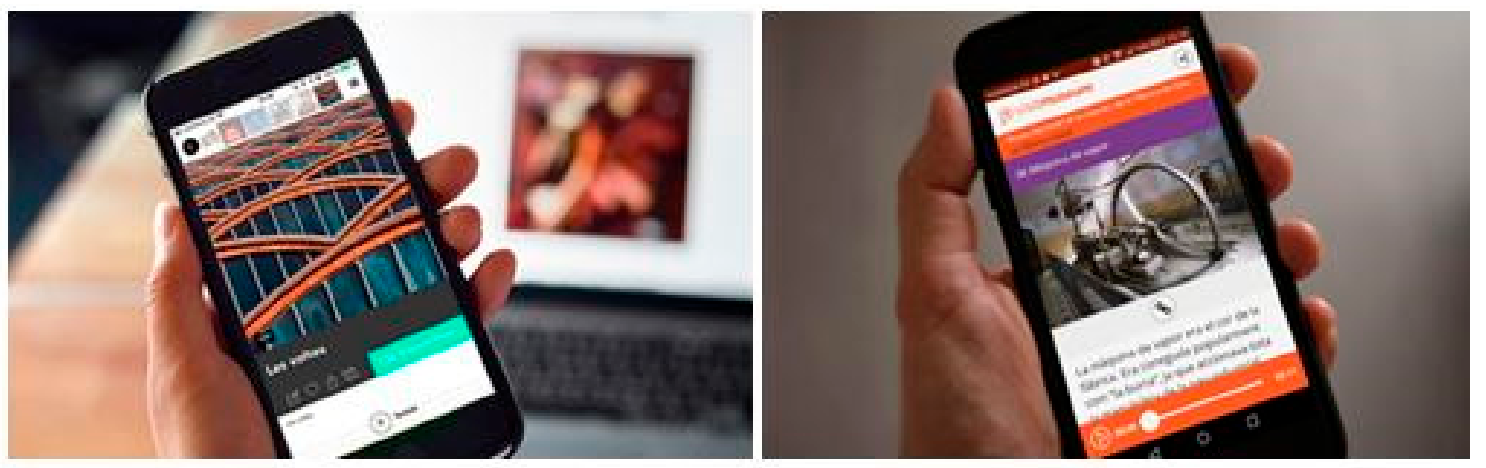

Figure 8. Several MNACTEC applications for smartphones. Left: Cloudguide App (virtual tour of the museum's objects and spaces); right: Visitmuseum App (audio guide of the Vapor Aymerich, Amat and Jover building). Source: MNACTEC.

The survey shows that those responsible for the destinations are aware that much remains to be done in terms of bringing in new technologies, despite the recognized advantages that these solutions afford in terms of more efficient and sustainable resource management. In $43 \%$ of cases, respondents considered that the sites are already innovative, but the very same percentage thought that they are not yet.

Around $57 \%$ of the sites have interpretive panels with QR codes and in $43 \%$ of cases, these codes are thought to already be included in some type of printed promotional material. These are still low percentages that should increase in the coming years out of necessity.

The last block of the survey (Block E) refers to the application of information and communication technologies. They are used in $61 \%$ of cases and, in addition, in $57 \%$ they are used both to know more about tourism demand and to improve the visitors' experience and manage existing resources more effectively. Broadly speaking, it can be said that ICTs are used more for promotion than for management, because $72 \%$ of technical managers agree on their validity for publicizing the values associated with the preserved elements of industrial heritage.

Table 4 summarizes the highest levels of acceptance by blocks and questions, and according to each industrial heritage building or area.

Table 4. Summary of the highest levels of acceptance per industrial heritage building or area, according to blocks and questions.

\begin{tabular}{cc}
\hline Building or Area & Blocks and Questions \\
\hline Riotinto mining area & $\mathrm{A} 1-6, \mathrm{~B} 7-9, \mathrm{~B} 12-13, \mathrm{C} 14-20, \mathrm{D} 21, \mathrm{D} 23, \mathrm{~N} 27-30$ \\
Almadén mining area & $\mathrm{NC}$ \\
La Unión mining area & $\mathrm{A} 2-6, \mathrm{~B} 7-9, \mathrm{~B} 13, \mathrm{C} 14-15, \mathrm{C} 20, \mathrm{D} 21, \mathrm{D} 24-26$ \\
Samuño mining area & $\mathrm{NC}$ \\
San Blas Ironworks & $\mathrm{A} 1-4, \mathrm{~A} 6, \mathrm{~B} 8-9, \mathrm{~B} 13, \mathrm{C} 14, \mathrm{C} 18-20, \mathrm{D} 21, \mathrm{D} 26, \mathrm{E} 29$ \\
Añana Salt Mines & $\mathrm{A} 1-4, \mathrm{~A} 6, \mathrm{~B} 7, \mathrm{~B} 9, \mathrm{~B} 13, \mathrm{C} 14-15, \mathrm{C} 17-20, \mathrm{D} 23, \mathrm{E} 27-30$ \\
Royal Glass Factory & $\mathrm{A} 1-6, \mathrm{~B} 8, \mathrm{~B} 12, \mathrm{C} 14-15, \mathrm{C} 17-20, \mathrm{D} 21-22, \mathrm{D} 25-26, \mathrm{E} 28-30$ \\
Royal Spanish Mint & $\mathrm{NC}$ \\
La Encartada Beret Factory & $\mathrm{A} 1, \mathrm{~A}, 3, \mathrm{~A} 4, \mathrm{~A} 6, \mathrm{~B} 7-10, \mathrm{~B} 12-13, \mathrm{C} 14-15, \mathrm{C} 17-18, \mathrm{C} 20, \mathrm{D} 21$, \\
Water lift & $\mathrm{D} 23, \mathrm{D} 25, \mathrm{E} 27-30$ \\
NC \\
Vapor Aymerich, Amat y Jover textile factory & $\mathrm{A} 1-3, \mathrm{~A} 5, \mathrm{C} 14-15, \mathrm{C} 17-18, \mathrm{C} 20, \mathrm{D} 21-22, \mathrm{D} 24-25, \mathrm{E} 27$ \\
\hline
\end{tabular}

Source: own elaboration. Note: A1 (Block A, question one; B2-4 (Block B, questions 2 to 4), etc. NC: no answer.

The last survey question, as explained above, was open-ended. Only in one case has there been an answer, specifically from the managers of the Riotinto mining area. The answer indicated that right now, they are actively working on steadily implementing new digital technologies. Another significant item of information they added was that in just one year after implementing the electronic ticketing system, the percentage of visitors to the mining park has risen by $45 \%$. This clearly points to 
the role that digital technologies can play in cultural resource management and promotion, in this case, in relation to the heritage linked to the industrialization and production techniques of times gone by.

\section{Discussion of Results and Conclusions}

This study created a model for analyzing the existing digital level in a series of industrial heritage buildings and areas, selected for their special significance in the conservation of built structures and industrialization landscapes, and for their current use as culture sites. This article represents a unique approach to a thematic area that is under-researched, perhaps because industrial heritage tourism is a very specific market and its ties to the latest innovation models are still undervalued.

The advances made in the digital ICT field have created previously unknown connections between visitors, visited spaces, and available resources. The interaction of these three aspects among themselves, and with the neighboring territory, is fostering a set of new-generation competitive capabilities that enhance the projected image of each place and consumer demand for these cultural goods.

Digital techniques are part of the more general methodological process of what is known as "territorial intelligence". This intelligence emphasizes geospatial databases, the creation of territorial observation laboratories, the characterization of all the players involved or the application of collaborative models between entities, managers, and visitors [3]. It is a global strategy that constitutes a kind of new approach in the most recent analysis of digitally innovative places, which involve several non-exclusively technological elements [23,30].

The most efficient and sustainable management models represent the transition from theory to practice, always necessary in an era of great technical opportunities and growing digital competitiveness. In industrial heritage buildings and areas, these models are particularly significant due to the very characteristics of the preserved assets and the profound environmental changes caused by decades of prolonged economic activity [26].Some geographical research is of great importance because it constitutes an empirical study on some specific case or subject related to new technologies in the field of industrial heritage [20]. This supposes a qualitative leap that surpasses reflections of a strictly theoretical nature and a relevant scientific contribution on the validity of new technologies in tourism management and promotion of industrial heritage.

The results achieved in this research-almost the first of its kind in the field of industrial heritage-related technological innovation-are evident and exceed any general and exclusively theoretical approach. The results in themselves represent an original perspective of the current context of technological change and an approximation to the human and technical efforts made in the museums and cultural centers installed in the material elements of industrialization. Another outstanding feature of the analysis is that it is easy to apply and operationally compared in other different environments.

The advantage of the selected places is that they became tourist attractions when the digital revolution started up, and so have always invested in technological solutions as a means to avoid being identified as a traditional destination. Many a difficulty has arisen applying innovations, sometimes due to a coordination between the different players involved, and others due to the strategic lack of cooperation networks between the different industrial heritage sites, the high front-end costs, and the technical complexity perceived in the early stages.

There are several parts to the analysis conducted during this research: first, a critical and reasoned review of existing scientific literature in this regard; and, next, the selection of the case studies, an in-depth examination of their webpages, and the completion of a survey by the technical managers and directors.

Digital intelligence is generally perceived as a good management reference and an excellent scenario for interacting with visitors. The levels of innovation found are not uniform, as occurs with other kinds of heritage, with their own features adapted to the surrounding territory and to the internal logic of each production process. This diversity inevitably delays any homogeneity in applying any digital innovation. 
The webpages have been studied using a broad set of qualitative variables and producing a web popularity index (WPI) that simply and efficiently summarizes the information available in each place. The case study with the highest WPI is the Almadén mining area. The fact that its varied digital content is so carefully presented could have to do with it having been listed, since 2012, as a World Heritage Site by UNESCO, due to its exceptional values associated with the mining and international mercury sales. The next most outstanding examples, in terms of general compliance with the variables, are the San Blas de Sabero Ironworks, Añana Salt Mines, Royal Segovia Mint, Royal Glass Factory of La Granja de San Ildefonso, Cornellà de Llobregat water lift, and Tarrasa Vapor Aymerich, Amat y Jover textile factory. All these case studies show above-average compliance of the variables established as an analysis reference. In the rest, the digital level drops and the information provided on the website is less complete.

The variable with the highest level of compliance refers to the presentation of interesting content, followed by the attractive design and well-structured content, smart event calendar log, online promotion of other representative tourist attractions, and integrated presence in social media.

The survey shows that the majority idea is that when applying technology, a decisive role is played by the economic cost, as well as the problems ensuing from its complexity. In any case, the majority opinion is that the selected places are evolving favorably towards being considered smart destinations $(66 \%)$.

The lowest scoring of all the blocks into which the survey was divided is the connectivity and innovation block, followed by the management block. In contrast, the sustainability and accessibility block is quite favorably perceived, especially regarding conservation of the landscape and available resources, the application of energy and water saving measures, and physical and digital accessibility to information. Notably significant in terms of the application of ICTs is their use in promoting tourism, and less in terms of ascertaining demand, resource management, and improving visitors' personal experience. Compensating for this imbalance is essential to improving the levels of digital intelligence and efficient management in the medium term, as well as to forecast the emergence of new consumer models with sounder criteria.

Several main objectives must be achieved in the coming years to boost technological innovation and overcome current difficulties. An objective will be the best coordination between the different public administrations and local agents. Another objective will be the strategic creation of collaboration networks between the different places of industrial heritage. It will also be important to seek for funding to reduce high technological costs in the early stages of innovation, and specialized technical assistance that reduces the complexity of the implementation and development of new technologies. With these measures and other complementary ones, the digital tools will expand the cultural and tourist opportunities. The measures will facilitate the management of industrial heritage sites and will serve to disseminate the values of a legacy of enormous scientific and technical interest, with appropriate digital media for each resource.

The process of technological improvement is slow and continuous over time, that is, in a permanent phase of change to introduce the necessary advances for the most active interaction with the cultural user in the selected places of industrial heritage. In some analyzed museum, the active effort for the progressive application of new technologies is recognized. As an example, the implementation of the electronic sales system has increased the final visits and the percentage of sales with this technical means. They are very important and significant advances for the near future and for the general recognition of a legacy of great cultural importance.

The spaces studied are all local ones. This represents an advantage for achieving the innovation and efficiency goals because the new management methods and tools have a faster impact in smaller spaces due to their lower environmental and constructive complexity. Digital advances have been important, but there is still a need to keep on extending the use of new technologies and interconnecting all technical and human components for the same purpose. That is the only way to build a smart ecosystem capable of successfully promoting the image of industrial heritage as a resource for cultural consumption. 
Funding: This research has been funded by the Research Challenges R\&D\&i Project entitled "Vulnerability, resilience and strategies for the reuse of heritage in deindustrialized spaces". Ministry of Science, Innovation and Universities, 2018 call. Reference: RTI2018-095014-B-I00. Lead Researcher: Paz Benito del Pozo, University of León.

Acknowledgments: I would like to express my thanks for the support offered by the technical managers of the places selected in the research, without which it would have been impossible to carry out the study. I am also grateful for the cooperation of José Fernández, at the UNED SIG Laboratory, for producing some of the figures included in the text.

Conflicts of Interest: The author declares no conflict of interest.

\section{References}

1. Lamsfus, C.; Alzur-Sorzabal, A. Theoretical framework for a tourism internet of things: Smart destinations. J. Tour. Hum. Mobil. 2013, 2, 15-21.

2. Buhalis, D.; Amaranggana, A. Smart tourism destinations. In Information and Communication Technologies in Tourism 2014; Xian, Z., Tussyadiah, L., Eds.; Springer: Irelnd, UK, 2013; pp. 553-564.

3. Luque, A.M.; Zayas, B.; Caro, J.L. Los destinos turísticos inteligentes en el marco de la inteligencia territorial: Conflictos y oportunidades. Investig. Tur. 2015, 10, 1-25. [CrossRef]

4. Boes, K.; Buhalis, D.; Inversini, A. Smart tourism destinations: Ecosystems for tourism destination competitiveness. Int. J. Tour. Cities 2016, 2, 108-124. [CrossRef]

5. López de Ávila, A.; García, S. Destinos turísticos inteligentes. Harv. Deusto Bus. Rev. 2013, 224, $58-67$.

6. Miralbell, O.; Sivera, S. New innovation networks in destinations 2.0. In XVI Simposi Internacional de Turisme id'Oci; ESADE: Barcelona, Spain, 2008.

7. Plaza, A.G.; Herrero, J.L.C.; Maldonado, A.A.; Rossi, C.; Olivencia, J.L.L. Sistema integrado de gestión de destinos. In VIII Congreso Sobre Turismo y Tecnologías de la Información y Las Comunicaciones TURITEC 2010; Universidad de Málaga: Málaga, Spain, 2010.

8. Buhalis, D.; Law, R. Progress in information technology and tourism management: 20 years on and 10 years after the Internet. The state of e-tourism research. Tour. Manag. 2008, 29, 609-623. [CrossRef]

9. Volo, S. Bloggers' reported tourist experiences: Their utility as a tourism data source and their effect on prospective tourists. J. Vacat. Mark. 2010, 16, 297-311. [CrossRef]

10. Gretzel, U.; Werthner, H.; Koo, C.; Lamsfus, C. Conceptual foundations for understanding smart tourism ecosystems. Comput. Hum. Behav. 2015, 50, 558-563. [CrossRef]

11. Troitiño, M.A.; Troitiño, L. Patrimonio y turismo: Reflexión teórico-conceptual y una propuesta metodológica integradora aplicada al municipio de Carmona (Sevilla, España). Scr. Nova. Rev. Electrón. Geogr. Cienc. Soc. 2016, 543, 1-45.

12. Suau, F. El turista 2.0 como receptor de la información turística: Estrategias lingüísticas e importancia de su estudio. Pasos. Rev. Tur. Patrim. Cult. 2012, 10, 143-153. [CrossRef]

13. Rojas-Sola, J.I. Patrimonio cultural y tecnologías de la información: Propuestas de mejora para los museos de ciencia y tecnología y centros interactivos de Venezuela. Interciencia 2006, 31, 664-670.

14. Guttentag, D.A. Virtual reality: Applications and implications for tourism. Tour. Manag. 2010, 31, 637-651. [CrossRef]

15. Chianese, A.; Piccialli, F. SmaCH: A framework for smart cultural heritage spaces. In Proceedings of the Tenth International Conference on Signal-Image Technology \& Internet-Based Systems, Marrakech, Morocco, 23-27 November 2014.

16. Chianese, A.; Piccalli, F.; Valente, I. Smart environments and cultural heritage: A novel approach to create intelligent cultural spaces. J. Locat. Based Serv. 2015, 9, 209-234. [CrossRef]

17. Gómez, A.; Server, M.; Jara, A.J. Turismo inteligente y patrimonio cultural: Un sector a explorar en el desarrollo de las smart cities. Int. J. Sci. Manag. Tour. 2017, 3, 389-411.

18. Pardo, C.J. Sostenibilidad y turismo en los paisajes culturales de la industrialización. Arbor. Cienc. Pensam. Cult. 2017, 193, 400. [CrossRef]

19. Álvarez, M.A. La herencia industrial y cultural en el paisaje: Patrimonio industrial, paisaje y territorios inteligentes. Labor Eng. 2010, 4, 78-100. [CrossRef] 
20. De la Peña, F.D.; Hidalgo, C.; Palacios, A.J. Las nuevas tecnologías y la educación en el ámbito del patrimonio cultural. $<<$ Madrid Industrial, Itinerarios $>>$. Un ejemplo de m-learning aplicado al patrimonio industrial. Tecnol. Cienc. Educ. 2015, 2, 51-82.

21. Buhalis, D. Marketing the competitive destination of the future. Tour. Manag. 2000, 21, 97-116. [CrossRef]

22. Aldebert, B.; Dang, R.J.; Longhi, C. Innovation in the tourism industry: The case of tourism@. Tour. Manag. 2011, 32, 204-213. [CrossRef]

23. Ivars, J.A.; Solsona, F.J.; Giner, D. Gestión turística y tecnologías de la información y la comunicación (TIC): El nuevo enfoque de los destinos inteligentes. Doc. Anàl. Geogr. 2016, 62, 327-346.

24. Perfetto, M.C.; Vargas-Sánchez, A.; Presenza, A. Managing a complex adaptive ecosystem: Towards a smart management of industrial heritage tourism. J. Spat. Organ. Dyn. 2016, 4, 243-264.

25. Pardo, C.J. The post-industrial landscapes of Riotinto and Almadén, Spain: Scenic value, heritage and sustainable tourism. J. Herit. Tour. 2017, 12, 331-346. [CrossRef]

26. Pardo, C.J. Environmental Recovery of Abandoned Mining Areas in Spain: Sustainability and New Landscapes in Some Case Studies. J. Sustain. Res. 2019, 1, 190003.

27. Pardo, C.J. El Patrimonio Industrial en España. Paisajes, Lugares y Elementos Singulares; Editorial Akal: Madrid, Spain, 2016; p. 286.

28. Pardo, C.J.; Martínez, J. Conservation, management and tourist use of pre-industrial heritage. Identification of Spanish experiences from a territorial analysis. J. Tour. Hosp. Manag. 2015, 3, 1-22.

29. Martín-Izard, A. A new 3D geological model and interpretation of structural evolution of the world-class Río Tinto VMS deposit, Iberian Pyrite Belt (Spain). Ore Geol. Rev. 2015, 71, 457-476. [CrossRef]

30. Caro, J.L.; Luque, A.; Zayas, B. Nuevas tecnologías para la interpretación y promoción de los recursos turísticos culturales. Pasos. Rev. Tur. Patrim. Cult. 2015, 13, 931-945.

(C) 2019 by the author. Licensee MDPI, Basel, Switzerland. This article is an open access article distributed under the terms and conditions of the Creative Commons Attribution (CC BY) license (http://creativecommons.org/licenses/by/4.0/). 